University of Louisville

ThinkIR: The University of Louisville's Institutional Repository

Electronic Theses and Dissertations

$1-1925$

\title{
The neutrality of Kentucky in 1861.
}

Jennie Angell Mengel 1872-1934

University of Louisville

Follow this and additional works at: https://ir.library.louisville.edu/etd

\section{Recommended Citation}

Mengel, Jennie Angell 1872-1934, "The neutrality of Kentucky in 1861." (1925). Electronic Theses and Dissertations. Paper 964.

https://doi.org/10.18297/etd/964

This Master's Thesis is brought to you for free and open access by ThinkIR: The University of Louisville's Institutional Repository. It has been accepted for inclusion in Electronic Theses and Dissertations by an authorized administrator of ThinkIR: The University of Louisville's Institutional Repository. This title appears here courtesy of the author, who has retained all other copyrights. For more information, please contact thinkir@louisville.edu. 
THE

NBUTRAIITY OF KENTUCKY IN 1861 


\section{UNIVERSITY OF LOUISVILLE}

THE

NEUTRAIITY OF KENTUCKY IN 1861

A Dissertation

Submitted to the Faculty

of the Graduate School of Arts and Sciences

In Partial Fuifillment of the

Requirements for the Degree

of Master of Arts

Department of History

By

Jennie Angell Mengel

1925 


\section{TABLE OT CONTENTS}

I

II

III

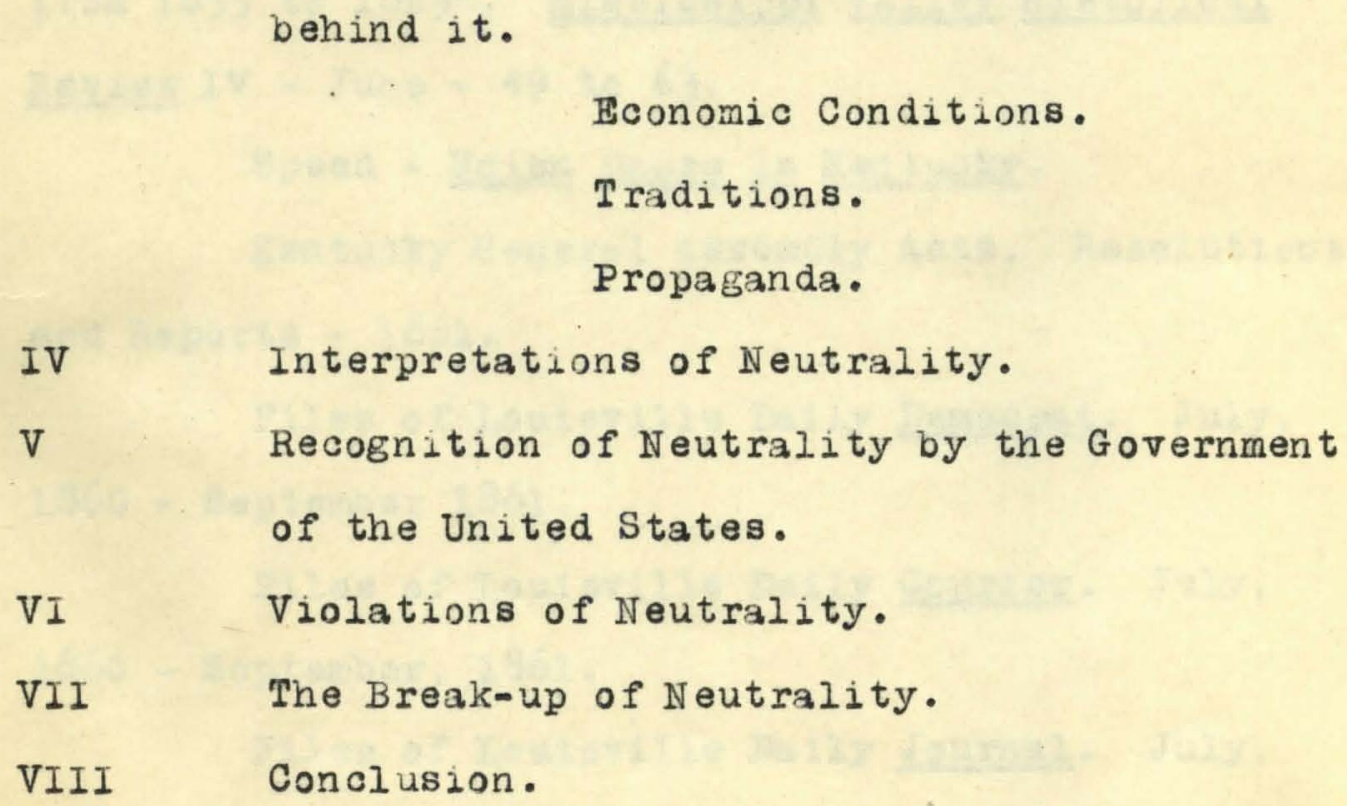


Chapters on Civil War in Kentucky histories by Motrlroy, Smith, Shaler, Collins.

"Neutrality of Kentucky in 1861", by A. C. Quissenberry. Kentucky State Historical Society Register, 1917.

"Neutrality of Kentucky in 1861", by Wilson Porter Shortridge. Mississippi Valley Historical Society Review. Narch, 1923.

Holt - Fallacy of Neutrality. An address to people of Kentucky at Louisville, July 13, 1861. Also a letter to J. B. Speed.

Robinson, J. R. - "Sectionalism in Kentucky from 1855 to 1865". Mississippi Valley Historical Review IV - June - 49 to 63.

Speed - Union Cause in Kentucky.

Kentucky General Assembly Acts. Resolutions and Reports - 1861 .

Files of Louisville Daily Democrat. July, 1860 - September 1861.

Files of Louisville Daily Courier. July, 1860 - September, 1861.

Files of Louisville Daily Journal. July, 1860 - September, 1861. 


\section{Preface}

During the year 1924 - 1925 a seminar on the Civil War in Kentucky was held in the University of Louisville under the direction of Dr. R. S. Cotterill of the Department of History. Among the subjects studied the Neutrality of the State in 1861 seemed to arouse the most discussion and the most divergent opinions. For this reason I have been interested in pursuing the subject further and in embodying the results of my study in this thesis. Most of the material on which the thesis is based has been presented to the seminar and been criticized by the members. 
Mr. A. C. Quispenberry in his article on "Kentucky Neutrality in 1861" (1) says, "At its spring session in 1861, the Legislature of Kentucky, if it had been put to the ultimate test of declaring either for the Union or for the Southern Confederacy would undoubtedly have declared for the Confederacy by a very large majority, and would have called a Sovereignty Convention which would certainly have enacted the secession of the State, and would have united its fortunes with those of the South. This fact was so well known, that the Union men of the State, many of whom were among its most prominent citizens, concocted the trick of neutrality, through which the evident trend of Kentucky sentiment was diverted from its channels in such a manner that the State was saved to the Union. This trick eventuated in the passage by the lower house of the Legislature, on May 16, 1861, a resolution to the effect, That this state and the citizens thereof should take no part in the Civil War now being waged except as mediators and friends to the belligerent parties, and Kentucky should during the contest occupy a position of strict neutrality. This passed the House of Representatives by a vote of 69 for and 26 against'," (2) 
It seems to me that Mr. Quissenberry is taking too much for granted in this statement; that he is indulging in a speculation which he cannot prove and that in attributing the position of neutrality to trickery he is imputing to Kentuckians a degree of stupidity that my twenty-eight years of residence among them will not permit me to concede. Mr. Quissenberry, however, is not alone in his opinion. Other writers of Kentucky history, including Collins, Smith, and Shaler, have made practically the same statements and have created what was an almost unchallenged tradition until Mr. Speed in his Union Cause in Kentucky made a spirited refutation of the charge.

From the two conflicting views of $\mathrm{Mr}$. Quissenberry and Mr. Speed regarding the political opinions of Kentucky in 1861, a person may, without any special knowledge of the circumstances, conclude that there were at least conditions in the State favorable to the promotion of neutrality.

Neutrality, at whatever time and in whatever place, must be based on apathy - indifference to the claims of opposing parties, or on a division of sympathy toward those claims, or on a conflict between sympathy and expediency - No one has yet arisen to accuse Kentucky of being apathetic or indifferent to the struggle, but the most casual student can 
appreciate that historically, socially, and geographically Kentucky was not merely committed to a division of sympathy but to a conflict between sympathy and expediency.

The most important factor, however, in leading Kentucky to a position of neutrality was not the clear cut division of the people according to their sympathies into two distinct groups, but the fact that there was still a third group of individuals, in each of whom there were contending loyalties and unbiased judgments; and this group of temperamentally neutral. people became the nucleus to which gravitated all those who, above everything else, feared and deplored fratricidal strife, those whose hopes were centered on mediation, and last but not least, those who, for material reasons, sought to prevent the invasion of the State, the devastation of the fields, the suspension of business, and the general economic loss which would come to a people who lived in the natural theater of war. To the various elements that made up this group, neutrality became a spontaneous expression of their desire for a mental refuge from their own indecision or a real refuge from the inevitable consequences of war.

Moreover, neutrality was a position in which a great many avowed Unionists were in perfect accord. - 
It so happened that while the Disunionists had open to them only one line of conduct, - that of precipitate secession into the Southern Confederacy, - the Unionists had a choice between two lines: They could actively support the Union by backing the Administration in its policies; or they could passively support it by merely refusing to give aid and comfort to its enemy, a line of conduct which appealed to the great majority of Unionists in that it seemed to reconcile their devotion to the Union with their disapprobation of the Administration. Neutrality was, moreover, a perfectly satisfactory position to all Unionists, willing to stand still and hold themselves in reserve for the time when action might be necessary and it had besides the advantage of throwing them into cooperation with those who were neutral because they didn't know which way to go, or didn't wish to go either way.-

Though it is easy to convince ourselves that the Kentuckians were not tricked into their position of neutrality, we raust confess that the period in which they tried or claimed to be neutral was a period in which a great game was being played between Unionists and Disunionists, with Kentucky as the stake, and that all the arts of strategy were practised by all players. The final winning of the game, however, was due to neither trickery nor skill but to 
the happy chance that the Unionists held the winning card of "material interest", - a card that has been the deciding factor in many, if not most, political games. 
The Neutrality of Kentucky in 1861

Its Economic Appeal

There is an old saying that "Coming events cast their shadows before them" and the elections of 1860 and the tenets of newly formed political groups seemed to be distinct foreshadowings of Kentucky's position in the war between the North and the South. The last contest in Kentucky between the two political parties, known as Whigs and Democrats, occurred in August, 1853, when representation in Congress and the legislature was pretty evenly divided. After that the Democratic party was opposed by the American or Know Nothing Party which, in 1855, elected C. S. Morehead as governor, six Congressmen, and a decided majority of the state legislature. The Know Nothing Party, however, was very short-lived and so we find in 1859 that the party opposed to the Democratic party had no more dignified nor significant title than "the opposition". In that year Beriah Magoffin, the Democratic candidate, was elected governor over Joshua H. Bell, and a very substantial Democratic majority was elected to the legislature. Governor Magoffin, of well known Southern sympathies, and this legislature, supposedly in accord with him, were in office when the crisis of 
1861 came upon the state. (3)

In August 1860, there occurred the election of local officials and one state officer the Clerk of the Court of Appeals -. The election, however, in view of the pending presidential canvas was heralded by the press of the state as being of paramount importance and as having a controlling influence for weal or woe throughout the whole state. Mr. Clinton MeClarty was the candidate on the Democratic ticket, or the Breckenridge ticket as it was popularly called. Mr. Leslie Combes was the candidate on the Bell - Everett ticket; of the party now known as the Constitutional Union party, but which a year before had been called "the Opposition" and which the Louisville Courier still designated as a "combination of odds and ends and factions". (4) It was a party entirely without organization anywhere in the state and so its victory by a majority of over 20,000 was doubly significant (5) and was generally considered by the Union press of the state as a preliminary defeat of Breckenridge, the Democratic candidate for president and one of Kentucky's favorite sons.

The Louisville Daily Journal which played no insignificant part in the election of $\mathrm{Mr}$. Combes, asked, "Do the people of Kentucky see the signifi- 
cance of it? For the first time in the history of our nation, we have a party organized to overturn the government, and Kentucky is degraded by having the leader of the Disunionists selected from this state. Who, upon reflection can be astonished that, from every hill and valley of our Commonwealth, the returns are pouring in to show that Kentucky repudiates this miserable party or that one of the darling and cherished sons of our state is ignominiously defeated in his first effort to wage war on the integrity of the Union, as it is? The result is brought about so quickly and in a mode so free from all vindictiveness of feeling that it seems evident that the blow had been struck not because Kentucky loved Caesar less but because she loved Rome more." (6)

The intervening weeks between the August and November elections were spent by both parties in strenuous efforts in developing organization and in carrying on, through press and platform, a somewhat acrimonious campaign. In this campaign Mr. Iincoln, was scarcely a factor, the candidates being, so far as Kentucky was concerned, Mr. Bell, Mr. Breckenridee, and Mr. Douglas. Mr. Breckenridge was generally understood to be standing for disunion and though this was repeatedly denied he suffered from the fact that all the papers which supported him advocated 
disunion with more or less frankness. Though the alignment of votes could not be considered as absolutely on the secession issue, for many people then, as now, voted in accordance with custom and tradition and because of inability to break away from old leaders, still one may consider that the combined vote of over 40,000 majority against $\mathrm{Mr}$. Breckenridge represented, in a general way, Kentucky's attitude toward the question of disunion. (7) 
The election of Mr. Lincoln precipitated the secession of South Carolina from the Union, but in Kentucky it became the occasion for a reassertion of loyalty to the Union. In spite of the fact that Mr. Lincoln had received only thirteen hundred votes in Kentucky, in spite of the fact that people had fervently prayed and worked against $h$ is election and now sincerely deplored it, yet they did not, on that account, despair of the country nor did they intend as the Journal expressed it, "to abandon her in any crisis which the unhappy event may bring forth." (8) The Journal, almost immediately, issued a clarion call to the men of the Border States and especially of Kentucky "to give prompt and unequirocal expression through public meetings to the deep and supreme feeling of loyalty to the Union which we believe animates our people to a man. We wish in this juncture to see the men of the Border States coming together, without respect to former party associations and joining in one common act of political worship around the altar of their country. Let all thought of party and all thought of men be expelled. from our bosoms in this period of trial. Let us rise superior to the behests of party and equal to the demands of the crisis. Let us be patriots, not partisans. Let us not in so fearful a juncture dis- 
credit the cause of the country by laying our unholy hands upon it.......... Let the grand collective voice of Kentucky go up and go abroad proclaiming to whom it may concern that she is still loyal to the core; that no taint of disunion infects her spotless robes, and that if the people of any other state or states attempt to dissolve the union, they must not look to the tomio of Clay and the home of Crittenden for sympathy or succor." (9)

Thus did George D. Prentice, editor of the Louisville Journal. bitter opponent of Abraham Lincoln, take up the work to save Kentucky to the Union. In reading, however, in the news items of the daily papers accounts of the meetings of people, irrespective of party, that were held in all parts of the state during the following weeks, one realizes that Mr. Prentice's call was not a suggestion to the people but was a reflection of their spontaneous desire to give voice to their feeling of loyalty. Henderson and Lexington share the honor of holding meetings within a week after the election, but other meetings, both of towns and counties, followed in quick succession. Stirring speeches were made and resolutions were passed, which though differently expressed had much in common. - All of them oppose the policy of Mr. Iincoln and are averse 
to the tenets of the Republican party: They regret the departure from ancient custom in the election of a president and vice-president from one section; they recognize the wrongs done by the North to the South in the attack upon a constitutional institution; they condemn such action, yet distinctly declare that it does not constitute a cause for secession; they condemn the reckless and precipitate action of the South and finally each and every meeting passes a resolution expressing unshaken loyalty in the Union. One cannot read over these resolutions without feeling that in a certain way they anticipate Kentucky's position of neutrality, and really foreshadow its very form and substance, forecasting a neutrality between warring factions; between black Republicanism and headstrong Secessionism: a neutrality, frankly critical of these two fanatical extremes. These resolutions show that their makers were perfectly conscious of the clear distinction between the forces temporarily in control of the governments and the Union destined for permanence, and they show evident signs that the neutrality between warring factions will never develop into neutrality between the Union and the Confederacy. Evidently these resolutions were veing carefully sorutinized and probably there were many 
anxious that they should not express a partial sympathy. A meeting of Louisville and Jefferson County, for which a call signed by over five hundred names had been sent out, was to be held on the evening of November $24 \mathrm{th}$ in the City Hall. On the morning of that date a letter signed "Main Street Merchant" was published in the Journal. The letter deprecated the tone of the resolutions passed in all the Union meetings (Oldham County excepted) as not quite conciliatory to the South. The writer says that while quite firmly and kindly rebuking the South for the extreme measures they would take, "let us tell them we are with them to the extent of demanding from the North a guaranty for the enforcement of the Fugitive Siave Law and this demand we will put forth with all the powers within our control". And he goes on to say that, "Commercially our relations with the South are of the most intimate kind and that wi thout her trade and influence the days of the prosperity of Louisville are numbered. It is all important therefore that the resolutions which shall be adopted in Louisville shall embrace such sentiments as will place us in a proper position towards the South as well as the North." It was thus that expediency coming from a dozen different angles began 
to shape Kentucky's policy.

An incident of the meeting in Louisville shows that the Disunionists were already beginning to sense the influence of these meetings on public opinion. It seemed that very early, before the hour appointed, a few only being present, Mr. Robert T. Durret, a Breckenridge leader, moved that Mr. Charles D. Pennybaker take the chair. After several well known Southern sympathizers had been appointed vicepresidents, Mr. Durret moved that a committee be appointed to draft resolutions, handing a written list to the chairman. (11) Before the committee had time to retire, however, people began to arrive and having discovered what was being done made other nominations (12) from the floor and thus thwarted the strategy devised to control the committee. As might be expected, two sets of resolutions were reported. The majority resolutions were eritical and put the blame for the conflict and for the inflamed state of public feeling upon the North though counseling patience for the South. The minority resolutions were more conservative and conciliatory and, a division of the house being called for, passed with only about one hundred dissenting in an audience estimated at between three or four thousand. (13)

The resolutions passed at this meeting were 
not different in spirit from all of the others. They expressed loyalty but not submission. They resolved, "That Kentucky shall stand by the Union, insisting on the faithful execution of every provision of the constitution by the United States, until the aggressions upon her constitutional rights have become more intolerable than revolution." Recalling the words of the minority report of the Federal Relations Committee at Frankfort, made nine months before, one is reminded that revolution is not necessarily secession. That report read: "The undersigned do not believe that Kentucky feels any sympathy for such revolutionary morements. Kentucky is ardently attached to the Union of the States. She will live in it and she will fall, if fall she must, in defense of it, whether attacks are made upon it by fors from without or from within. If her sovereign rights shall ever be violated by the General Government and no peaceable redress can be obtained, she will resort to the rights of revolution and by the help of $\mathrm{God}$ and her own strong arm she will endeavor to obtain redress. But if she ever resorts to the right of revolution, she will fight for redress in the Union and not out of it." (14) This resolution seemed still to express the feelings of the Louisville meeting. Rights had been violated but secession was not the remedy. 
Whether Governor Magoffin had given ear to the tenor of the resolutions passed in these Union meetings all over the state it would be difficult to say, but certainly the letter (15) written to the editor of the Frankfort Yoeman in response to the question 'What will Kentucky do', showed a distinct modification of the view expressed in his inaugural address and in his address to the legislature at the opening of its regular session. In both these addresses he took a stand for secession as the only remedy for certain wrongs. In the letter he seems to prefer to gain his rights under the aegis of the constitution and the banner of the Union. The Louisville Courier in an editorial on the Governor's letter approved of much of it but took exception to the statement that he looked for redress of wrongs and protection of rights to peaceful measures under the Constitution and in the Union. The Louisville Journal commenting on the letter said, "The Governor recognizes that the American Constitution was made to endure hardships and encounter opposition. It was not chimerically constructed merely for an era of good feeling and such hearty fellowship that hardly any government at all would be required. So many ages of preparation and so much wisdom of sacrifice expended in its construction were not employed in 
hollowing out a frail canoe to float in calm and placid waters and be overwhelmed and dashed to pieces by the first waves of a rising storm. The Constitution is a staunch and noble vessel launched upon the mighty deep of human passion, waywardness, and self will, and designed to meet and outride the storm which these may at any time excite, and to carry forward the people of the United States to the goal of national prosperity, greatness, and glory to which a benignant Providence has pointed them." (16) Thus the editor of the Journal graciously attributed sincerity of conviction to the Governor; but viewed with the perspective of the Governor's later actions one is inclined to doubt that anything more was back of his seeming altered opinion than a mere temporary concession to the voice of the people. 
In considering the attitude of a state or people in any great political crisis a due recognition must be given to organization and the election of $\mathrm{Mr}$. Iincoln seemed to put a new and almost incredible impetus into the organization work of Kentucky where competition between parties was so keen. A few days after the election of $\mathrm{Mr}$. Iincoln a letter was addressed to Messrs. Harney, Hughes and Co. of the Louisville Democrat by Mr. C. A. Wickliffe. Mr. Wickliffe wrote of the danger of secession and the breakup of the Union, adander that was so much more critical than in 1832 "because", as he said, "the Southern leaders know that Jackson is not president." Mr. Wickliffe did not concede that the right of peaceful secession exists and said that forcible resistance to the execution of the laws of the United States by citizens of any state though acting under the authority of such state is treason in such persons. He was anxious that people in Kentucky speak upon the subject and speak in a tone and a manner which would be understood at home and abroad. He proposed therefore, "That the State Committees who think as we do upon the subject shall forthwith jointly call a convention of citizens, in such mode and manner that each county opposed to secession shall send delegates to represent them in such mass conven- 
tion."

........... In earnestly urging the above proposition", wrote Mr. Wickliffe, "I do not appeal to party. This is a time for patriotism not partyism; a time for the prompt exercise of reason, unclouded by passion and unbiased by prejudice. I appeal therefore not to any party but to the brave and loyal citizens of the entire commonwealth to come forward and rebuke sectionalism and declare in tones of thunder that the Union must and shall be preserved." (17)

Whether in response to the suggestion of $\mathrm{Mr}$. Wickliffe or not, I do not know but on December the 4 th it was announced that a Democratic State Union Convention would be held on January the 8 th in Louisville. (19) A few days later the state Central Committee of the Constitutional Union party announced a convention for the same time and place. (18)

It was explained by those who had the conventions in charge that the purpose of holding two conventions in Louisville on the same day was that they might the more easily form a perfect union between the two parties. As the tenets of these two parties were absolutely irreconcilable excepting on the question of the preservation of the Union, any co-operation between the two would have to be on that one issue alone, and the fact that they were willing to put aside all their 
differences of opinion is an indication of their great devotion to the Union and their great fear for its existence.

Delegates to the Democratic Union Convention met in Concert Hall in Louisville on the day appointed. The meeting was presided over by Bx-governor Charles A. Wickliffe "whose venerable look carried one back to the days when there were giants in the land, - whilst his lucid and powerful refutations of the heresy of secession reminded the listener that we have still amongst us some scattered representations of that fading age." The Constitutional Union Party met in Mozart Hall. It was called to order by Judge William F. Bullock and elected John L. Helm as permanent chairman.

In both conventions speeches were made by many, deprecating the Southern movement, blaming the fanaticism of the North, but breathing a spirit of devotion to the Union. Bach convention appointed members to a joint conference committee, which met and drafted a set of resolutions that were adopted unanimously by both conventions. A Union State Central Committee was appointed consisting of prominent leaders in both parties, and a resolution was passed calling on delegates to call County Conventions for the purpose of endorsing the resolutions.

In these resolutions it was distinctly 
stated:

That Kentucky favored remaining in the Union which would not cost a tithe of the forbearance and patience to save that it cost their ancestors to make:

That a president elected by one section opposed to an institution of another was a test of patriotism and forbearance not a cause of dissolution: That the South, in having a majority in both houses of Congress had security and that if the antislavery party should increase in strength and be able to carry out its purpose in the use of the Federal Government, the South had means of resisting unconstitutional aggression and ought not to adopt hastily the last resort:

That the Constitution of the United States is not a compact to be broken at will of each:

That it favored calling a Border State Convention:

That if Kentucky be represented in any convention, delegates be elected by the people. Finally the Crittenden Resolutions were approved and hope expressed that a compromise might yet be arranged between the sections.

Mr. Speed (21), in his Union Cause in Kentucky, says: "The fusion of these two large elements of the 
people of Kentucky made a deep impression. The Douglas and the Bell - Everett tickets had polled in the 1860 elections two-thirds of the vote of the state and now they clasp hands in the one supreme task of saving the state from rushing into secession. The echoes of the Conventions did not die away for many days. In all parts of the state meetings were held approving their spirit and resolutions." What is to be noted about the resolutions is their extreme moderation - their spirit of conciliation - which Mr. Speed attributes to the discretion of the Unionists. He says: "It would have been suicidal to have used expression; in speeches or resolutions, which would have been interpreted to mean complete accordance with all that was so abundantly charged against the Northern people. If they had not been discreet all would have been lost."

I, however, fail to find in the resolutions evidence of either the marvelous discretion attributed to the Unionists by Mr. Speed or the trickery of which Mr. Quissenberry accused them. Certainly the Unionists did not approve of all that was abundantly charged against the Northern people nor of all that could be proven against them, and in admitting their disapproval they showed sincerity rather than discretion, though they had discretion in store for every need. At no time during those critical months did they weaken their 
position by any indiscreet or ill-considered action. There was plenty of opportunity for the use of discretion during the special legislative sessions in January, March, and May 1861. (22) As has been said the legislature had been elected in 1859 and was supposed to be in accord with the governor who was openly in sympathy with the South. This fact accounts for the great pressure that was brought to bear on the governor by the Disunionists in favor of an extra session of the legislature for the purpose of calling a convention to determine Kentucky's action. The Louisville Courier was particularly insistent that the governor call the extra session, saying: "The disruption of the Union is inevitable and in view of the event which cannot be provented Kentucky must determine her future." (23)

The Unionists on the other hand opposed the extra session arguing that if disruption is inevitable, it is too late for the legislature to consider preventive measures and too early to deliberate intelligent1y, when the precise scope and bearings of the dread event are as yet unknown; that the excitement which prevails in the commonwealth will be most unfavorable if not fatal to the calm deliberation which befits the consideration of a question of such unspeakable moment. Thus the Disunionists were for precipitate action while the Unionists were for a policy of deliberation and 
moderation, a policy which found ultimate expression in the Declaration of Neutrality.

Mr. Prentice, the supporter and leader of this policy, wrote: (24) "Kentucky has done her part so far. Kentucky has solemnly remonstrated with the people of the Southern states against the unconstitutionality and precipitency of their course and they have told her scornfully to keep her remonstrances to herself. She has assured them in tones of greater tenderness than they deserved that she is ready to cooperate with them in all lawful and suitable measures of redress for existing grievances and even in revolutionary resistance itself if intolerable aggressions should hereafter render such resistance necessary, and they have sneered at her fearless and loyal people and called them submissionists. She has respectfully expostulated with them against the injustice of rushing blindly into revolutions without regard to the counsels or the vital interests of those whose rights and honors are most deeply concerned, and they have replied with contemptuous insolence, 'we intend to drag you into a revolution after us'. And now, in defiance of Kentucky's assurances, remonstrances, and expostulations, they are on the point of actually starting in revolution. South Carolina, we believe, starts to-day. The first act is closed. What more could Kentucky do if she would? 
What more ought she to do if she could?"

Such were the arguments against an extra session but they were of no avail, and in response to the call of the governor (25) the legislature convened January 17, 1861. Governor Magoffin in his message assumed that the Union of the States was already dissolved and suggested the calling of a State Convention for the purpose of deciding Kentucky's future action. He also urged the arming, equipping, and providing munitions of war for the State Guard. In making these recommendations the tone and manner of the governor showed perfect assurance that they would be acted upon as he desired; and the general opinion among the people was that the legislature would be in accord with every proposal of the governor.

As the weeks went by, however, the legislature from which the Disunionists had hoped so much became to them more and more of a disappointment. It did nothing more drastic than to appeal to the Southern people to stay the hand of revolution and to retum and make one mighty effort to perpetuate the noble work of their forefathers: nothing more radical than to protest against the use of force or coercion by the General Govemment as unwise and inexpedient and tending to the destruction of the country: and nothing more definite or practical than to apply to Congress 
to call a National Convention to amend the Constitution, requesting the legislatures of all the other states to join in this application and appoint at the same time delegates to a preliminary conference in Washing ton.

Having done this, and without taking any steps toward calling a convention or arming the state, the legislature adjourned on February 11 to reconvene on March 20. In the following session the legislature still clung to its original line of action, called a convention of the Border Slave-holding States, provided for the representation of Kentucky therein, and then adjourned sine die. In the month that followed many things happened. Fort sumpter was fired upon; President Lincoln called for 75,000 troops and Governor Magofin sent a spirited refusal to (26) comply with the call for Kentucky's quota. It was the most critical period in the history of the state and the governor called the legislature to assemble on May 6 to consider once again the action of Kentucky.

The seizure of Fort Sumpter was considered by the Northern people as an act of wanton aggression, and kindled in them a flame of resentment which discarded Kentucky's calm and wise protests as completely as the South had discarded her friendly appeals. The counsels of Kentucky were set at naught equally by the 
general government and by the seceding states. As Mr. Prentice expressed it, Kentucky stood "morally, politically and to some degree physically between two armed and hostile camps on the brink of actual civil war. On the one side is the Government, to which we owe allegiance and in the preservation of which we feel that the best hopes of ourselves and of mankind are treasured up: on the other side are communities to which we are allied by similarity of institutions and by ties of commerce and affection, but who are attempting insanely to overthrow and blot out from the list of nations our common government. Both have disregarded our expostulations, and in our solemn conviction, the dread abetrament to which they are resorting, if adhered to obstinately can end in nothing but the destruction of all that both hold dear."

What should, what would the Kentucky legislature do in such a crisis?. That was the supreme question of the hour, not only in Kentucky but in the nation as well.

What the legislature did has been told at the beginning of this thesis and, though no one now debates the tremendous effect for good that was involved in that legislative decision, the motive that prompted it is still a subject of controversy.

It would be foolish to deny that in a legis- 
lature which sent John C. Breckenridge to the United States Senate strategy would play no part in committing it to a policy opposed by $\mathrm{Mr}$. Breckenridge and his party. It would be equally foolish to ignore the fact that the Unionists in their effort not to antagonize used discretion to the superlative degree and thereby brought upon themselves the accusation of duplicity. It was, however, in my opinion, neither trickery nor tact that saved Kentucky from secession but the voice of the people answering the question in every conceivable form of popular expression; through letters and speeches of thousands of individuals; through resolutions passed in hundreds of meetings; and through the uncontrovertible returns of the ballot boxes at every election, the last being the election of delegates, on May 4, to the Border State Convention. (28)

Mr. Quissenberry has said that the idea of neutrality first originated in the fertile brain of Mr. Lincoln. (29) I do not know. The seed may have come from Mr. Lincoln's fertile brain and (to continue the metaphor) it may have been sowed broadcast, as they tell us, by Union leaders; but the all important factor, whether one is cultivating onions or opinions, is the soil. And I do know that the soil of Kentucky, 
plowed and harrowed by tradition and material interests was ready for neutrality.

The motto, "United we stand - Divided we fall" was emblazoned on Kentucky's escutcheon. The inscription, "Under the auspices of heaven and the precepts of Washington, Kentucky will be the last to leave the Union" was carved in the marble slab she contributed to the Washington Monument. These were part and parcel of Kentucky's traditions. It was a tradition that was strong and dependable and yet so tremendous was the influence of material interest that the influence of tradition might have been eliminated without jeopardizing the cause of neutrality in Kentucky.

Mr. Robert F. Breckenridge in an address (30) made in Lexington on the National Fast Day, proclaimed by the President, said; "What I shall chiefly attempt to show is that our duties can never be made subordinate to our passions without involving us in ruin, and that our rights can never be set above our interests without destroying both...........Men may talk of rights perpetually violated: They may talk of injuries that are obliged to be redressed: They may talk about guarantees without which they can submit to no peace: There is much that has force and much more that is captivating to ardent minds in such expositions of our sad condition. I will not consume the 
short time allotted to me in examining such views. What I assert in answer to them all is, that we have overwhelming duties and incalculable interests which dictate a special line of conduct, the chief of which should be the preservation of the American Union and therein the American Nation."

Those duties and interests were graphically set forth by Mr. Breckenridge in that memorable address. They were set forth again and again by every Union orator and every Union editor in the state. In reading in the papers of that period the countless speeches made and editorials written by both sides in that struggle I am impressed with these facts; That over against every Union appeal to duty the Secessionists could set just as eloquent an appeal for rights and that there was after all more lure in an appeal for rights than in an appeal to duty: That whenever Union writers and speakers went into the arena armed with political theories they met antagonists armed with theories as sound, as tried, as valid as their own. It was only when they fought with the weapons of material interests that they found the Secessionists helpless before them for the Secessionists, so far as Kentucky was concerned, had nothing with which to combat the great economic arguments in the interest not 
merely of the immediate welfare and safety of Kentucky but of her future prosperity and security.

They were not mean arguments. There was much that was high and noble in them; much that was idealistic in spite of the fact that their predominant ingredient was common sense. The setting forth of these arguments by press and platform and pulpit would to-day be called propoganda, a comparatively recent word for a very old thing. And propoganda it was; propoganda used with a skill that excites our admiration. This fact, however, must always be kept in mind when estimating the influence of propoganda and that is that it takes not only where the soil is ready and that generally it flourishes and bears fruit in proportion to the arnount of truth which it contains. 
Let us see what was the nature of some of those appeals.

Kentucky had already suffered great economic loss because of the disturbed political conditions. Throughout its history the people of the state had enjoyed great prosperity and the present business depression was often skillfully used to generate resentment against the South. Ex-governor Helm in a very remarkable address (3l) at a meeting in Hardin County, said: "We appeal to our brethen in the South to pause for mature and considerate reflection, to invite cooperation in Council. You justly appreciate our losses by Northem aggression, but allow us in frankness to as sure you, that you have by your precipitate action in one short month depreciated our property in value greatly to exceed all our losses from the fanaticism of the North. Your action has disturbed the currency, prostrated commercial interests, resulting in the ruin of many of our most enterprising men. Already has more individual injury been done than can by industry and legitimate trade be righted up in years. You are provoking the deadly hate of thousands who might otherwise sympathize with you. A people who strike to overthrow a government, hitherto the idol of its people, cannot hope to succeed, no matter how just the cause in their own eyes, by showing a disregard 
for the interests and a contempt for the opinions of others."

Very many people have thought that all the slave holders in Kentucky were naturally arrayed on the side of the Secessionists, when as a matter of fact a great many of the wealthiest and most prominent of the slave holding class were strong Unionists. It is not to be questioned that genuine love for the Union and respect for its Constitution and its laws were at the base of their loyalty, but they must have been, nevertheless, influenced greatly by the possible and probable effect of Kentucky's withdrawal from the Union upon the status of slavery in the state.

In the speech, made by Dr. Robert F. Breckenridge (30) in Lexington, he said, that if the slave linge was made the dividing line, all slave states seceding and all free states remaining in the Union, "The possibility of slavery remaining in any border state terminates at once. In our affected zeal for slavery we will have taken the most effectual means of extinguishing it." Many others stressed the point that the Fugitive Slave Law would no longer be exercised and that Canada would be brought to the very doors of Kentucky.

Space forbids us to quote the fervid appeals that were made by a portrayal of the results of Kentucky's secession upon trade and industry, by which all 
the people either directly or indirectly would be affected. Probably the most universal appeal was based on taxes. Taxes at their best are far from popular and the estimates of the cost of starting a new government and building up a new army and navy, all to be paid by direct taxation had no particular lure for Kentuckians. It struck them that they would be paying dearly for an enterprise they had opposed. The condition of South Carolina was described by many a graphic pen: "Look at the condition of the people of South Carolina", wrote Mr. Prentice (33), "ground down by forced loans, taxed $\$ 16.00$ per head for their negroes, with prospect of incomparably more frightful taxation, cut off from all commerce by the act of their own authorities, prostrated in business and overwhelmed with general bankruptcy, starving or eating beef at thirty-five cents a pound, and a constant advance in price, arranging their affairs so as to save a pittance from their ruined fortunes........... Look at the people of South Carolina in the first stage of her secession and revolution and reflect that this condition, aggravated tenfold in horror and distress by our geographical position, will be ours if we follow the insane example South Carolina has set."

These specific appeals were, however, as nothing compared with the appeal made by the general 
welfare and safety of Kentucky, the protection of families and the sanctity of homes. When after the bombardment of Fort Sumpter, the legislature was called to decide on Kentucky's action, no one in the state was allowed to be ignorant of what was involved. If Kentucky seceded it would be equivalent to a declaration of war against the United States and Kentucky would become a theater of war. The myriads of soldiers from Ohio, Indiana, and Illinois, estimated to be five times as many as the soldiers of Kentucky and many times better equipped, would pour into the state, and ravage and lay waste everything in their way - and "our people" said Mr. Prentice, "even though every man of them were equal to one of the old Knights of Palestine would be too few to withstand them for a day." ........... If Kentucky remains as she is, protesting as she has done, that she will aid in no warfare against the Government of the Confederate States and protesting with equal earnestness that she will participate in no war against the Government of the United States, deeming that she but discharges her duty when as an armed neutral she guards her own soil against invasion from either side and uses her authority and, when necessary, her physical strength to keep the belligerent powers apart, neither the North nor 
the South will venture to disturb her position. She will in that case be at peace and her rights will be neither outraged nor menaced by any section."

In an editorial in the Journal April 28, 1861, Mr. Prentice drew a never to be forgotten picture of what Kentucky might expect if she withdrew from the Union. "Let us suppose that Kentucky has seceded in a blaze of glory...........The act of secession will be a signal for war and the seat of that war will be our own soil. Northern armies will invade us. The Confederates will bring their legions to attack the North. We shall have the drum and fife, the bugle and the roar of artillery, marching, foraging parties, bivouacs, camps, skirmishes, and all 'the pride, pomp and circumstances of war'. All our people will lay down the shovel and the hoe to grasp the musket and the rifle. War will be the great occupation of the inhabitants, and who will be left to sow, harvest, and garner the harvests? Who will tend the cornfields, the tobacco patches, and the hog droves, which must be well cared for to prevent a famine? Where will the provisions come from to feed the Cofederate army? The Cotton States have not enough for their own use, and we, of Kentucky, have had hard work to keep our meal and corn bins filled after the partial failure of our last 
crops. But fighting is a very appetizing exercise. Soldiers cannot live on glory without their rations of hog and hominy; they must have beef, too; the cavalry horses and the sturdy animals that draw the cannon must have provender, and the commanders must have old Bourbon and Catawba for their private messes. Where will all the flocks and herds, the crops and vineyards be found to supply all this demand? The answer is plain enough, for the foraging parties will seize upon your prize cattle, your hay, housed for your farm mules next winter, and the perfect extract of corn or grape, laid by for your own use, will be confiscated to the use of war and military necessity. War confiscates everything eatable and drinkable to its capacious maw, although it may all the time be glutted with human blood and gore. Thus we pass a glorious summer campaign and victory may perch upon our banners; the rattlesnake may hiss its delight and the pelican cluck out its 'Io triumphe. Now for the feast and barbecue in honor of our great achievements'. But where are the viands and the oxen? The solid glebe has been unbroken by a furrow though many have been plowed upon the brows of fathers who mourn their gallant sons, and of widows not to be comforted for the loss of their sturdy supporters; the hoof of the war horse, the tires of the 
gun carriages and caissons, and the heavy tread of armed battalia have cast the only seeds for the year's tillage, and famine, desolation, empty garners, and sterile cornfields have been the crop of dragons' teeth to pinch and bite and starve! The soldier tired of war's alarms receives his discharge and with a bounding heart, although perhaps a limping gait, he starts for his home - that home which he has dreamed of before the watch fires and rememberes when,

'Peace was tinkling on the shepherd's bell, And singing with the reapers.'

and what does he find but the marks of rapine, lust, and all the odious concomitants of war............ ye fathers and brothers of Kentucky, who know not the terrors and havoc of war, who think only of its glory and not of its evils, who living safely and guarded in your interior positions, have not felt the shock of former conflicts nor had all the unchained horrors and demons of hell brought to your very doors, would that we could paint in colors sufficiently glaring to impress you, the misery, destruction, havoc, tumult, carnage, and despair which attends on gaunt and ferocious war."..........(34)

It was with such words of fire, that Mr. George D. Prentice, in those critical days following 
the bombardment of Fort Sumpter, sought to lead Kentucky into its position of Neutrality. If Kentuckians had been a less loyal people; if devotion to the Union had not been part and parcel of their bone and sinew, they would have hesitated to elect such a future as was portrayed by men whose tongues and pens were consecrated to the saving of Kentucky from a direful fate. But they were not tricked by this portrayal into opinions that were artificial. The speakers and writers of that day were all saying only the things that were reflections of what was being said in simpler, cruder words in homes in every part of the state. Possibly all that Mr. Prentice and other writers and silver tongued orators did was to arouse in the people more respect for and more confidence in their instinctive opinions when they heard or saw them expressed in terms that defied denial.

In trying to place a value, however, on the arguments which emphasized the material interests and welfare of the people one must not undervalue the appeals made to Kentucky's sense of pride and loyalty. It is true, in my opinion, that material interests alone could have turned the state to Neutrality; but material interests were not alone. They were powerfully aided by Kentucky's loyalty to the Union and a 
pride in her past history, both of which held her from secession, and by an unswerving belief in her responsibility as a mediator which turned her to neutrality. And we must admit that these things of the spirit - loyalty and pride and hope - lent themselves to an eloquence and to a brilliance of writing that stirred the souls of Kentucky people while the arguments in behalf' of welfare or safety were merely convincing to their minds.

On a day, shortly before the legislature met Mr. Prentice wrote: "For what are all these horrors to be met? Why is Kentucky in the midst of peace, happiness, and prosperity asked to throw them all away and go to war? What is she to fight for, or against whom is she to contend? The Government founded by Washington and Madison has never wronged her; the most perfect comity has existed between her and the governments of her sister states; she has been beloved and honored; old Kentucky has been a spell to move whole communities; and the reverence of the American people is accorded to her as the resting place of Henry Clay. There is not a state in the Union which would not arm to protect Kentucky in the Union if she were menaced by foes from without. Hands of friends in peaceful grasp are extended to her from every quarter, and yet 
she is asked to commit the insanity of rejecting the proffered friendship, of contumeliously shaking off old lifelong friends and returning the kind greetings by assuming an attitude of war. And for what? Who can answer without stultifying himself or perverting facts to make out a case of fancied wrong. Maddened passions rule the hour and blind perversity hurries us to the brink of the fearful precipice. Kentucky true to her history, and loyal to the precepts of her fathers may prove a nucleus around which the friends of civil liberty and true republicanism can rally for the preservation of that glorious governmental fabric which has been the wonder and admiration of the whole world..... „.......Men of Kentucky, pause and reflect, lest you act rashly; Victory will bring anguish and defeat will insure disgrace: but calm considerate action will arrest the flow of blood, restore our citizens to their deserted fields and avert the terrors of cruel war. From the mouth of the Ohio to the mouth of the Big Sandy, we would fling the stars and stripes at intermediate distances as emblems of our loyalty and white flags as symbols of our neutrality and thus armed in the panoply of peace Kentucky would stand like a giant breakwater upon which the waves of faction might dash harmlessly and the tempest of war spend its force." (35) 
In trying to present to you the motives that actuated Kentucky in deciding upon a position of neutrality I have quoted freely from Mr. Prentice, a great editor of what was doubtless the greatest newspaper in the state if not of the South. At such times of political crisis newspapers are eagerly and thoughtfully read and widely discussed. Editors are for that reason more influential for weal or woe than any other class of people and upon their shoulders alone must often rest the responsibility for changes in the political tide. I suppose if the responsibility governing Kentucky's Declaration of Neutrality had to be put upon the shoulders of any one man that man would be George D. Prentice who doubtless would shoulder it with pride. As it happens, however, neither he nor any other man nor group of men can be given the praise or blame for that legislative decision.

At the beginning of this thesis I flouted the idea of Kentuckians being tricked into Neutrality and maintained that they were neither lured nor driven into that position. I am willing to go a step further and say that they were not even led. Leaders there were indeed, but they were headers not in the sense that they were blazing a trail or guiding a people along an 
unbroken path. They were leaders merely in the sense that, because of ability or zeal, they were in the forefront of a movement - an almost spontaneous movement of people along a route that had been mapped out by economic conditions and inherited traditions. 
To affirm the neutrality of Kentucky was one thing; to maintain it was quite a different and much more difficult thing. The complexity of the problem was principally due to the fact that neutrality had not been explicitly defined and meant different things at different times and was never the same thing to all people.

The idea of neutrality arose when there was a hope that there would be no bloodshed, and the position was definitely assumed before that hope had departed and when it was still believed that Kentucky might yet be the mediator and intercessor between the states. - This position of the state was generally understood and had been explicitly presented. On the 27 th of May the Border State Convention met in Frankfort and issued, during its week session, two addresses, one to the people of the United States, and one to

- the people of Kentucky. In the latter it was stated, "Your state on a deliberate consideration of her responsibilities, moral, political, and social, has determined that the proper course for her to pursue is to take no part in the controversy between the Government and the seceded states, but that of mediator and intercessor............ Kentucky was right in maintaining this position because from the commencement of this deplorable controversy her voice was for recon- 
ciliation, compromise and peace." (36)

It was in accord with these views that the position of Kentucky became known as "Mediatorial Neutrality", - a term that could be consistently used only as long as mediation seemed possible.

As the struggle progressed and grew in proportion and possible duration neutrality developed into what became known as "Armed Neutrality", - the excuse for this position being that Kentucky must be ready to defend herself against possible violations of her neutral position by either side.

What constituted violations depended entirely upon what constituted neutrality, and divergent views regarding neutrality led to bitter accusations of violation.

Some of those who had been sympathetic with the secession idea were induced to favor the position of neutrality in the belief that when Kentucky declared herself neutral she absolved herself from all obligations to the Federal Government. Others saw in such an interpretation, a direct act of rebellion and claimed that the state could not absolve herself from any constitutional ooligation; and that, though the state might assert neutrality so far as furnishing troops for either side by direct state authority and 
thereby avoid becoming involved directly in her state capacity in a war with either side, she could not by such act deprive the Federal Government of the right to exercise within the limits of the state any constitutional right it might possess.

Just how divergent were the views on this subject may be realized from reading the editorials in the Louisville Courier and the Louisville Journal during the summer months following the declaration of neutrality. The Courier, in its endeavor to make the people understand its interpretation of Kentucky's position, said: "The law of nations regulating the actions of neutrality declares that it is an essential character of neutrality to furnish no aid to one party which the neutral is not equally ready to furnish to the other," "The neutral is not to favor one party to the detriment of the other," "Even a loan of money to one of the belligerent parties is considered to be a violation of neutrality," "No use of neutral territory for the purposes of war can be permitted," "No proximate acts of war are in any manner to be allowed to originate on neutral ground," "No act of hostility is to commence on neutral ground," "No measure is to be taken that will lead to immediate violence," "The neutral is to carry himself with perfect equality between both beligerents." Thus the Courier interpre- 
ted and demanded what would have been in fact "Strict neutrality".

The editor of the Journal in commenting upon this conception of neutrality said: "Now the editor of the Courier knows as every other man of ordinary intelligence knows that the word, neutrality, as used by the friends of the Union in this state had no such meaning. He knows that such an absurd interpretation of the position of the Union party was expressly and emphatically repudiated by every Union organ and every Union candidate in the state. To allege that the position was ever intended to be thus understood is to attempt to practise a gross deception. It has been explained 100 times and needs to be explained 101 times that the men of the dominant party in Kentucky in declaring for neutrality declared only that Kentucky ought not as a state to furnish troops for the war, and that she would oppose a movement of either of the two belligerent powers to send any army upon her soil for aggression upon the other. - They never said nor thought of saying that Kentucky should not in all matters perform her whole obligations and duties as a istate of the Union.......... The paragraph copied above from the Courier is absurd. Meant to be shrewd, it is only silly. The editor talks of 
Kentucky as being to all intents and purposes an independent neutral sovereignty between two warring nations. He would have his readers think that Kentucky bears in all things the same relation to the Southern Confederacy as she bears to the United States. We11, he may make them think this if they are fools certainly not otherwise. Does the United States possess no rights except in common with the Confederate States? Is not Kentucky a part of the United States? If she is not, when and by whose act or authority did she cease to be so? Doesn't she have senators and representatives in the Congress of the United States, participating in the legislation of the United States and drawing their salaries from the United States Treasury? Has not she a Custom House and United States Customs officers within her borders, collecting United States revenue under United States laws and paying them over to the United States government? Are not United States Courts held within her limits by United States judges, expounding United States laws, and having their decisions executed by United States marshals? Are there not nearly one thousand United States post offices and postmasters in Kentucky and are not United States mails carried all over the state at the expense of the United States? What miserable nonsense is it for secession 
editors, in hot pursuit of their unhallowed ends, to say that Kentucky is just the same and has the right to be just the same to the Confederate States as to the United States - that she is a sovereign power, an actual nation, alike independent of the two and equally free from obligations to both!

The Courier and the rest of the secession organs threaten us with the vengeance of the Southern Confederacy if Kentucky shall consent to the payment of taxes to the United States Government. The vengeance then might as well come now as wait. Kentucky is all the time paying taxes to the United States Government, Kentucky, in common with all other states in the United States bears the expenses of the United States Government, thus paying United States taxes, and if this is a violation of neutrality let those who resent it go to work in their own way as soon as they like. The Union men of the state are determined to abide faithfully and scrupulously by the principles of neutrality, the only kind of neutrality they ever declared for, a neutrality perfectly consistent under all the circumstances with the highest and best loyalty to the United States and they will not be driven lightly from their determination". (36)

It was thus the editor of the Journal inter- 
preted neutrality and quite consistently began to use the expression, "loyal neutrality". The great difference between the "strict neutrality" of the Southern sympathizers and the "loyal neutrality" of the Unionists afforded constant opportunities for accusations of bad faith that obviously must lead to the break up of neutrality.

Before touching upon succeeding events which led to that conclusion it might be well to state briefly the recognition that was given to the neutrality of Kentucky by the Federal Government.

Naturally the decision of Kentucky, being of paramount interest to the United States Government, attracted a great deal of interest among Federal authorities. Barly in June General John B. McClellan. Commander of. United States troops north of the Ohio, invited General Simon Bolivar Buckner (37), Inspector General of the Kentucky Militia, to meet him in Cincinnati to discuss the subject. General Buckner was accompanied by Sam Gill (38), a Union man, and together they entered into a free discussion of opinions and conditions in Kentucky with General McClellan, resulting in General McClellan agreeing to a definite policy with regard to that state which General Buckner regarded as binding and which he reported to Governor 
Magoffin in the following letter:

\begin{abstract}
"General Buckner to Governor Magoffin Headquarters of Kentucky State Guard
\end{abstract} Louisville, June loth 1861.

Sir -

"On the 8th inst. at Cincinnati, Ohio, I entered into an agreement with General G. B. MoClellan, Commander of the United States troops in the states north of the Ohio river, to the following effect, "The authorities of the State of Kentucky are to protect United States property within the limits of the state," to enforce the laws of the United States in accordance with the interpretations of the United States Courts, as far as the law may be applicable to Kentucky and to enforce with all the power of the State our obligations of neutrality as against the Southern states, as long as the position we have assumed shall be respected by the United States.'

"General McClellan stipulates that the territory of Kentucky shall be respected on the part of the United States -even though the Southern states shall occupy it; but in the latter case he will call upon the authorities of Kentucky to remove the Southern forces from our territory. Should Kentucky fail to accomplish this object in a reasonable time, General 
McClellan claims the same right of occupancy given to the Southern forces. I have stipulated in that case to advise him of the inability of Kentucky to comply with her obligations and to invite him to dislodge the Southern forces. He stipulates that if he is successful in doing so he will withdraw his forces from the territory of the state, as soon as the Southern forces shall have been removed.

"This he assures me is the policy he will adopt towards Kentucky,

"Should the administration hereafter adopt a different policy he is to give me timely notice of the fact. Should the State of Kentucky hereafter assume a different attitude he is in like manner to be advised of the fact.

"The well known character of General McClellan is a sufficient guarantee for the fulfillment of every stipulation on his part.

I am, Sir, Very respectfully, Your obt servant, S. B. Buckner Inspector General"

The magnanimous attitude of the Federal commander made a very good impression in Kentucky and 
probably induced many who favored neutrality to pin their faith in Union leaders. - Certainly the special election for members of Congress held June 20, 1861 showed that there was little secession sentiment in the state. Union and States Rights candidates were nominated. The Union candidates won in nine of the ten congressional districts by a majority of 54,670 . After General MoClellan had definitely accepted Kertucky's official position, Governor Magoffin was inspired to seek recognition from President Lincoln and sent General Buckner to Washington to secure his approval. General Buckner was accompanied by John J. Crittenden and after presenting the plans of Kentucky to the President, received from him an unsigned paper which read

$$
\text { "It is my duty, as I conceive it, to sup- }
$$

press an insurrection existing within the United States. I wish to do this with the least possible disturbance or annoyance to well disposed people anywhere. So far I have not sent an armed force into Kentucky; nor have I any present purpose to do so. I sincerely desire that no necessity for it may be presented but I mean to say nothing which shall hereafter embarass me in the performance of what may seem to be my duty." 


$$
\text { July } 20-1861
$$

Signed ( J.J. C.)

He explained that he did not sign it because he did not wish to write a proclamation but simply to give to General Buckner a paper on which to base a statement of his policy and he asked Mr. Crittenden to identify the paper which was done by affixing his initials in the left-hand corner. (40)

This statement of Mr. Iincoln's became widely known and also made a good impression in Kentucky and in conjunction with some very indiscrete remarks made by Confederate officials about the same time helped to swell the Union victory in the August elections when a Union legislature was elected with a majority of forty-two (42) in the House and sixteen (16) in the Senate, representing a popular majority of between fifty and sixty thousand.

The significance of the vote in the July and August elections cannot be over-emphasized. It has been stated many times that the vote at both of these elections was a vote for neutrality and that if the question of neutrality could have been eliminated and the issue could have been clear cut between the Union and Secession parties, the vote would have been in favor of secession.

Soon after the election in July, the Paducah 
Herald said, "The election has closed. The result shows the complete triumph of the Union in the State. trery district, we believe, excepting the glorious and unterrified old First has elected Union men to Congress..........The result mortifying as it certainly is occurred from the blunders and false policy of our friends in every portion of the state except below the Tennessee River. In the Purchase men boldly threw out the banner of secession and where the contest was distinctly made upon that issue we have triumphed gloriously by thousands. (41) In nearly all the balance of the state where the contemptible dodge of neutrality was adopted by our friends the result has been shamefaced defeat........... one will for a morient doubt that Magoffin, Breckenridge, Powell, Stevenson, Hodee, Simrs, Talvot, Wathen, Cissell and others are all secessionists and have been working to take Kentucky out of the Union and place her with the Confederate States but the misfortune is, that they did not go rightly to work to accomplish this; they approached it by indirection instead of by a bold, manly, honest, open fight for secession. Had they thus fought our conviction is that they would have won the state by a triumphant majority; they acted on a mistaken policy and we have lost the state 
and would have lost even the First District had not a few bold men forced the true issue and won the district by the innate power of the truth of secession." In conclusion the editor begs that in the August election the secessionists be honest, come out in the open and fight on the fair issue of secession.' Certainly this is a frank confession on the part of the Paducah Herald and a remarkable conclusion for which I can find no basis.

If the people of Kentucky were secessionists at heart why should they, in the interest of neutrality, give their support to the Union party merely because it was advocating neutrality and fail to support the States Rights party which at that time was just as ardentiy advocating neutrality. Presumably the people did not need to vote the Union ticket in order to show favor to neutrality and if they did so it was because they had pierced the insincerity of the States Rights party on that issue long before the Paducah Herald's confession.

This editorial of the Paducah Herald was reprinted in the Louisville Journal July 21, 1861 with terse comments by $\mathrm{Mr}$. Prentice on what he calls the "moribund confession of the Herald", and he asks, "On what ground do they (the States Rights candidates) 
pretend to be entitled to the votes of the people; not on the ground of secession, for they profess to be for neutrality; not on the ground of neutrality for they are really for secession. Disunionists stand upon nothing. In disowning secession for neutrality they confessed the shame and ruin of secession. In convicting themselves of professing neutrality to effect secession they show the hollowness of their neutrality."

This death-bed confession of the Herald brought no success to the States Rights party and the results of the August election as quoted above prove to me several things, viz, that the people of Kentucky really wanted to be neutral; that they doubted the sincerity of the neutral professions of the States Rights party and preferred to trust the cause of neutrality to the Union Party. It is perfectly evident, moreover, that when they voted for Union legislators, they did not merely wish to trust the cause of neutrality to the Unionists but they also wanted to make sure that if there should be any deviation from neutrality it would be in the interest of the Union cause.

Just before the election, news of the battle Bull Run (fought July 21 - 61) had made it evident 
that mediation would be impossible and that the position of neutrality would undoubtedly be abandoned as soon as the legislature met. The election of a Union legislature under those circurnstances dispelled all anxiety as to the loyalty of the state.

Up to this time there had been no explicit violations of Kentucky's neutrality by either belligerent. Both parties had established recruiting stations just beyond the borders; the Confederate at Camp Boone near Clarksville, Tennessee and the Federal' at Camp Clay opposite Newport, Kentucky and at Camp Joe Holt opposite Louisville. At each of these camps volunteers for service were being enrolled but these could scarcely be considered as violations of neutrality.

From the time of the August elections, hov ever, there were many mutual accusations of bad faith. The Southern Confederacy and the States Rights party in Kentucky were particularly critical of the estaplishment of Camp Dick Robinson. This was a Union Camp in Gerrard County, established by General William Nelson in August 1861 and to which he was gathering recruits from all parts of Kentucky, presumably with the authority of President 
Iincoln. Governor Magoffin acting on the presumption that this was a violation of neutrality sent a commission to Washington to ask for its removal. Mr. Lincoln's reply is of great interest:

"Washington, D. C., Aug . 24, 1861.

To his Excellency B. Magoffin,

Governor of State of Kentucky.

"Sir: - Your letter of the 19th inst, in which you urge the removal from the limits of Kentucky of the military force now organized and in carn within the state is received.

"I may not possess full and precisely accurate knowledge upon this subject; but I believe that it is true that there is a military force in camp within Kentucky, acting by the authority of the United States, which force is not very large, and is not now being augmented.

"In all I have done in the premises, I have acted upon the urgent solicitation of rany Kentuckians, and in accordance with what I believed and still believe to be the wish of the majority of all the Union-loving people of Kentucky.

"While I have conversed with many eminent men of Kentucky, including a large majority of her memiers of Congress, I do not remember that any one 
of them, or any other person, except your Excellency and the bearers of your Ixcellency's letter has urged me to remove the military force from Kentucky, or to disband it. One other very worthy citizen of Kentucky did solicit me to have the augmenting of the force suspended for the time.

"Taking all the reasons within my reach to form a judgment, I do not believe it is the popular wish of Kentucky that this force shall be removed beyond her limits; and with this impression I must respectfully decline to so remove it.

"I most cordially sympathize with your Hxcellency in the wish to preserve the peace of my owm native state; but it is with regret that I search and cannot find, in your not very short letter any declaration, or intimation that you entertain any desire for the preservation of the Federal Union.

\section{Your obedient servant}

$$
\text { A. Lincoln" }
$$

On the same day that this commission was sent to President Lincoln, a similar commission was sent to President Davis asking for assurance that the neutrality of Kentucky would continue to be respected. President Davis replied that "the Southern 
Confederacy will continue to respect the neutrality of Kentucky, so long as the people of Kentucky will maintain it themselves. But neutrality to be entitled to respect must be strictly maintained between both parties."

This reply was not very reassuring in as much as President Davis felt that Kentucky had not respected neutrality herself nor forced the United States to respect it. Besides the establishment of Camp Dick Robinson there was criticism of the acceptance on the part of Kentucky of the embargo which unt

was off the commercial intercourse of Kentucky with the Southern States; of the secret conspiracy to obtain arms from the Iincoln government and to put them in the hands of such as would pledge themselves to obey the law; of the vote of Kentucky congressmen in favor of a money grant.

An editorial in the Courier September 14, 1861 detailing these offenses ends, "All af these things or the half of them or almost any one of them would have fully justified the Confederate States in ordering their forces into Kentucky."

The Unionists on the other hand maintained that none of those things were violations of neutrality but mere conditions forced upon them by the 
58.

necessity of being prepared to resist threatened invasion by Confederate forces massing on the border of Tennessee or forced upon them by the obligation of Kentucky's membership in the Union.

Commenting on the accusation that Camp Dick Robinson was a violation of neutrality the editor of the Louisville Journal (42) said; "We personally know that Judge Bramlet, in command of Camp Dick Rob inson has declared with emphasis that his purpose is and has been from the first simply to resist invasion and under no circumstances to make it.

"To allege that Kentuckians cannot, in and around their ow homes, enroll themselves, without a violation of neutrality, for the defense of these homes under the only flag to which they ever did or ever can owe allegiance is to mock common sense. The reason why encampments are deemed necessary to Kentucky's self-defense is obvious to all minds. Tennessee has an army at Cumberland Gap whose camps are pitched within fifty yards of Kentucky's line. Tennessee has a second army on the $I$ \& $N R R$, a third at Camp Boone, a fourth at Union City. She has armies posted on the whole dividing line between herself and Kentucky and her undenied and undisquised purpose is to watch vigilantly the movements of Kentucky and to 
be ready to pour overwhelming hosts upon her soil at any moment. This condition of things has existed for a long time and Tennessee, as if made arrogant by the conscious power it gives her, has committed during the last six months, more encroachments, injuries and insults than any independent nation ever committed upon another independent during a similar period.".......

"Knowing all this," Mr. Prentice continues, "many Kentuckians devoted to neutrality and not having the slightest desire to violate it felt that; inasmuch as Tennessee had all these thousands of men on the border at no cost to herself but kept there by the Confederate Government, the necessary counter army, composed of Kentucky men, should be supported by the Federal Government."

Beside the massing of troops on the border the Unionists accused the Tennessee authorities of seiging and controlling the Mississippi river and thereby preventing free navigation of that stream, greatly to the detriment of Kentucky citizens; of seizing boats at Memphis belonging to the people of Kentucky and confiscating same to their own use; of seizing the $L$ \& $N R R$ and using the stolen road for purposes inimical to the welfare of the people of Kentucky • 
Bach of these and many other offenses would between independent commonwealths be an act of war. Mr. Prentice complained that Governor Magoffin, whom he derided as a weak Uriah Heep, was patient and docile as a lamb under this abuse, desecration, and insult. "That while Tennessee spits in his face and takes him by the nose with impunity, the General Govermment scarcely dares look toward Kentucky for fear of arousing the ire of the volcanic Beriah Magoffin" and he asks "will not Tennessee while her hand is in, do Kentucky one favor by stealing her governor. Let her do that, and all her other thefts will be forgiven."

The Louisville Courier of August 8, 1861 published conspicuously the following official notice: "Military Notice to Kentuckians, Nashville, Tennessee. "The Southern Confederacy has consented to accept a regiment or more of men on the following conditions.

"For twelve months service - for service nearest to their homes with their own organizations as to field and subaltern officers, and in the awsence of a rms wherewith to supply them, to admit them with their own shotguns and rifles - those to be paid for on a 
fair valuation by a Government agent, so soon as said troops are mustered into service. Those desiring to avail themselves of this favorable invitation can learn further particulars by sending an agent to Hampton Station, on the M C \& I R R Tennessee, who may call on George W. Hampton. Northern Kentuckians preferred."

Thus it appears the Confederate Government had formally authorized individuals to raise for the Confederate service a regiment or more of men within the borders of Kentucky.

The Journal in commenting on this fact said, "Such an outrage, if sanctioned by the Government of Great Britain; or the Govermment of France, or the government of any other neutral country would call forth instantly from our government, a demand for explanation, which, if it were not complied with promptly and satisfactorily would be followed at once by a declaration of war."

While conspicuously parading this advertisement, the courier, through its editorial column, was objecting to troops encamped in Gerrard County, saying, "It is right and proper that these encampments should be broken up. The stationing of Federal troops on Kentucky soil is manifestly a violation of 
neutrality and of course ought not to be permitted by the state authorities."

In speaking of this encampment in Gerrard County, which secessionists called a breach of neutrality, and wanted the state government to break up, Mr. Prentice in Journal of August 21 wrote, "When the doctrine of neutrality was first announced, it meant no more and no less than that Kentucky as a state should not furnish men in the existing war. While we have often expressed the wish that the time might never come when anyone would deem it necessary to have an encampment of Federal troops in Kentucky, we have never dreamed nor has any man of sense ever dreamed that our neutrality would be violated if Kentuckians should choose to enlist upon their own soil under the flag of their country.........The Union men of Kentucky never thought of denying this constitutional right to any Kentuckian; and it is the highest impudence in Secessionists to talk about driving out of the state, or dispersing native born Kentuckians assembled for the preservation of thernselves, their state and their country and violating no law, of state, or nation."

Such was the state of public opinion, full of mutual accusations, criminations and recrimina- 
tions, when the new Legislature met on September second.

There was not only criticism on both sides of what had been done but there were direful suspicions as to what each side was preparing to do and each side seemed determined to be prepared to meet or to forestall if possible the plans of the enemy.

In the Danvilie Review in June 1862, Robert T. Breckenridge gives an account of what he calls the "Secession Conspiracy and its Overthrow". According to Dr. Breckenridge the Secession leaders met in Scot County on August 17 and formulated three plans. 1st. The armies of Polk and Zollicoffer and the troops along the Tennessee border were to simultaneously invade the state and there should be a simultaneous rising of secessionists within the state.

2d. That Governor Magofin should issue a proclanation calling on all true secessionists to rise; that secession members of the legislature should convene and by them the state should be put into the Confederacy. 3d. That Governor Magoffin should demand of President Iincoln the removal of Camp Dick Robinson. 
Now whether these plans really existed and were definitely known to the Unionists or whether they were merely suspected it is difficult to determine, but real or imaginary, the result was the same in stimulating the Unionists to place the state in a position of defense.

Mr. Speed in his Union Cause in Kentucky says, - "At the moment of supreme peril the conspirators encountered a degree of spirit and courage superior to their own and out of a condition apparently hopeless there sprang as by a single effort a combination of irresistable strength."

On August 29, twelve days after the secession conspiracy meeting in Scot County, a conference was held at Camp Dick Robinson. The conspiracy was discussed and a messenger was dispatched to Governor Magoffin to warn him on behalf of General Nelson and a responsible meeting of loyal citizens that the plans of the Secessionist leaders were understood that any movement by force of armed men would be promptly met by force and that the Governor would take notice that by being thus advised beforehand was meant among other things that they would hold him personally responsiole for whatever might happen through his neglect or connivance. 
The same messenger was to take orders from General Nelson to the commander of the Home Guards at Frankfort that he must occupy the arsenal with a sufficient force to hold it relying on immediate assistance if opposed. If overpowered before relief came he was to spike the guns and blow up the arsenal.

Messengers were sent to General Rousseau at Louisville, to commanders of Home Guards at Louisvill. Lexington, and Covington that steps should be taken to complete the preparation of all the loyal troops of the state. Such was the condition of affairs when the legislature met on September the second.

On the next day (September 3) General Polk, with Confederate troops from Tennessee, entered the state and occupied and fortified the strong positions of Hickman and Columbus. On September 5, the Federal troops by order of General Grant occupied Paducah.

Under the circumstances the action of the legislature was watched with interest and excitement not merely by the people of the state and neighboring states but by the nation as a whole.

The Clarksville, Tennessee Chronjcle of September 13, 1861 summed up the issue as follows, 
The position of the Kentucky Legislature is a most embarassing one. If it declare for neutrality, a war with Iincoln must be the consequence because neutrality cannot be enforced without driving out his troops. If it declare for Iincoln, the Confederate States will at once make Kentucky a battleground; and if the Legislature attempt the inefficient policy of 'holding with the hare while running with the hounds', it will leave the matter where it is, the state invaded by both belligerents and fast becoming the theatre of desolating civil war. From this there is no escape and Kentucky must take her stand on the one side or the other. Neutrality is an exploded humbug. There is no longer a chance to avert the war which it was intended to stave off. All that remains for the people to do is to decide whether they will fight for the South and liberty or the North and despotism." In these concluding words the chronicle shows that it has entirely overlooked the fact that the people of Kentucky had already decided what was to be done. Had decided it in the August elections when the people gave the government of the state into the hands of a Union legislature, which on September 11. two days before the appearance of the article in the Chronicle had passed a joint resolution instruct- 
ing the governor to inform those concerned, "that Kentucky expects the Confederate and Tennessee troops to be withdrawn from her soil unconditionaldy."

This resolution passed the Senate by a vote of 21 to 8 and the House by a vote of 71 to 26.

Immediately after this vote had been taken a resolution was introduced in the House that "the Governor be requested to demand from those in authority the immediate withdrawal of the Federal troops from the Southwestern part of the State." This was lost by a vote of 71 to 29 .

The joint resolution was vetoed by Governor Magoffin with the explanation - "Unless ......... it is the purpose of the General Assembly to abandon all pretense of neutrality and to commit Kentucky to active co-operation with the United States Government, ......... I cannot conceive why notice shall be given to one party and refused the other."......... The answer to this veto was prompt and the resolution was reenacted in the House by a vote of 68 to 26 and in the senate by a vote of 25 to 9.

The meaning of the resolution was obvious but lest anyone should misunderstand its import the General Assembly was not content with asking the Confederate Army to withdraw but passed a resolution to 
the effect that the invaders must be expelled, requesting General Robert Anderson to take command and to call out a volunteer force for the purpose of repelling the invaders, that the Governor be requested to give all the aid in his power, that he call out the military forces of the State and place same under General Thomas L. Crittenden. These resolutions, likewise vetoed, were reenacted over the veto which marks, says McElroy, the point at which Kentucky officially abandoned neutrality and declared her adherence to the Union.

The break up of neutrality in Kentucky was of vast import to the Federal Government. If Kentucky had espoused the Southern cause the Union victory might have been indefinitely postponed and it is not difficult to conceive that the war might have been carried to the lakes instead of the gulf and the ultimate result might have been the exact reverse of what it was.

The factors that played a part in a decision of such vast importance are interesting to consider. They were in many particulars the same factors that influenced the people to declare for neutrality. Both decisions were first of all decisions against secession; different from each other only in deg ree. 
One can form some idea of the various factors that were influential in the decision by reading the newspapers of the period. By noting what appeals were being made by editors and public speakers of the day one can form an opinion as to what were the things that really counted in influence, for these editors and speakers kept a finger on the public pulse and were not apt to waste ink or breath on unessentials.

There was always the tremendous appeal to the duty and loyalty and courage of Kentuckians, but taking precedence even of these was the appeal to a love of peace that animates the soul of every man, woman, and child. It had been a deciding factor in the declaration for neutrality and was still an important factor in the decision for the Union.

On July $29 \mathrm{Mr}$. Prentice had a wonderful editorial in the Louisville Journal on the "Paths to Peace". This was when there was still hope of maintaining neutrality, but the argument held good when that hope had been abandoned and still holds good today. At that time there were some who felt that Kentucky, even though not allied with the Confederate States, should recognize them as an independent nation. Mr. Prentice argued that the path to peace 
was not in recognition of the Confederate States but in the preservation of the Union and he made one of his many brilliant appeals to save it. "The peace and prosperity of the continent and the hopes of the world demand it. Without the salvation of the Republic there can be no peace that he who is at once a statesman and a lover of his race can deem worthy of pursuit or desire." "The destruction of the Republic would expel peace and all the virtues and interests and glories of peace from the continent forever. It would extinguish civilization and order in the Western Hemisphere. The Republic must be saved; its salvation is the path and the only path to solid and enduring peace."

In the open letter of Hon. Joshua Holt to Mr. J. F. Speed which was printed in several papers in the state and which was also put into wide circulation in pamphlet form, Mr. Holt wrote that "if the principle of secession is maintained we shall be a mass of jarring, warring, fragmentary states, enfeebled and demorifalized, without power at home or respectability abroad, and like the Republics of Mexico and South America we will drift away on a shoreless and ensanguined sea of civil commotion from which, if the teachings of history are to be trusted, 
we shall finally be rescued by the iron hand of some military wrecker who will coin the shattered elements of our greatness and our strength into a diadem and $a$ throne."

It is not strange that the people of Kentucky were moved by considerations of this sort and that many of them adhered to the Union cause with something of the same fervor that animated many Americans who in the last great war believed that their country was waging a "war to end war".

There are some people in Kentucky even today who resent a statement that anything else played a part in Kentucky's adherence to the Union other than her traditional loyalty, her patriotism, her love of peace, her chivalry and courage in defense of a beloved flag. One cannot, however, read the papers of that period and note the emphasis that was being placed by both sides on considerations of safety, prosperity, economy and general material advantages without realizing that the propagandists of both the North and the South appreciated that after all those might be the deciding factors.

The Louisville Courier had said if Kentucky joins the Southern Confederacy troops will be stationed along the northern frontier to protect slavery. 
In commenting on the Courier's statement the Joumal said (32): "So for the privilege of being under the government of the Confederate States, we are deliberately to create a necessity for a permanent military cordon seven hundred miles in extent. Who is to pay the expense of this perpetual occupation of nearly a thousand miles of frontier by a long drawn out army. To place sentinels within a quarter of a mile of each other along the Kentucky frontier would require an army of nearly 3,000 men and an expedition of nearly $\$ 2,000,000$ a year. And after all what sort of resistance could four sentinels to the mile make to a rush of twenty, fifty, or a hundred armed slaves. Talk not of expedients for guarding slavery in Kentucky, if the Ohio River were made the dividing line between two independent governments. The speedy, the almost immediate disappearance of slavery from our midst could be prevented by no human agency. That's a truth which every Kentuckian of common sense recognizes. The secession of Kentucky from the United States would be the secession of slavery from Kentucky."

The Secessionist newspapers were bitter in their protests against Kentucky paying the tax levied by the Federal Government to carry on the War, (Kentucky's quota was $\$ 800,000)$ and they endeavored to 
alarm the people over the amount. The Unionists, on the other hand, called attention to the recent issue of government notes, not to exceed $\$ 100,000,000$ by the government at Richmond and reminded the people that Kentucky, if a part of the Southern Confederacy, would have a quota of $\$ 12,000,000$.

An editorial in the Journal, Septemoer 4, 1861, on "Paying the Tax" concludes, "It is perfectly clear, we presume, to every mind that Kentucky must do one of three things. She must, as a state of the United States, pay the tax levied upon her in common with the rest of the states or she must erect herself into an independent sovereignty and pay her own tremendous taxes as a separate and distinct nation of the earth, or she must go into the Southern Confederacy and pay the taxes imposed by the Confederate Government. The idea of making Kentucky an independent nation to support all the vast expenditures of such a nation is, of course, entertained by no one.

"The only escape then for Kentucky from the $\$ 800,000$ tax of the United States Governyent must be in to the Confederate Government. And, oh, what an eseape that will bel Our people have seen the provisions of the war tax bill of the United States and those of the war tax bill of the Confederate States. The latter 
not only impose by far the heavier tax upon everything taxed by the former, but also taxes slaves, mer chandise and other kinds of property not taxed by the former at all. The war tax of Kentucky, were she a member of the Southern Confederacy would now, instead of being less than $\$ 1,000,000$, be not less than $\$ 12$, $000,000 \ldots \ldots . .$. And it may be well to consider what the means of payment would be after secession into the Southern Confederacy. As a member of the Confederacy she would, of course, be at war with the United States and not only that but she would be, as we all know, the main theater of that conflict. All her fields would be swept by fiery devastation, everything belonging to her would be destroyed. If it would now, when she is in profound peace, be difficult to pay less than $\$ 1,000,000$, levied upon her, we may imagine what her condition would be, if, with war's awful tide of blood and fire raging through her borders she were called on by the stern volce of despotic power to pay that amount multiplied indefinite$1 y$.

"It is well for the Legislature and the whole people to look things squarely in the face and to meet and grapple them as they are. War is a fearful thing. War exists in this country by no fault of 
Kentucky, but alas, do what she may, she must bear a portion of its evils. It is the part of wisdom for her to choose the sraallest, necessary portion."

No one can doubt that Mr. Prentice was keenly interested in the preservation of the Union and would have it preserved regardless of cost, but in this editorial and in many others he presents the practical truth of financial cost and he certainly would not have taken the trouble to do this if he had not believed that the understanding of this practical truth would be an important factor in preserving the Union.

Harly in September the Union men might very naturally be depressed over the recent reverses suffered by the armies of the Union in Virginia and Missouri and by the tremendous military power displayed by the South and by the fact that there were, overhanging them on the Tennessee border, four military encampments. Knowing that it was a vital matter to the Union men to know what support they could count on in case of invasion, the Cincinnati Commercial of september 3, 1861 attempted to set forth what could be relied on. It reminded Kentucky that the three months men had all been disbanded and that the men in the Union armies were all there for three 
years or the duration of the war, - gave the number of regiments then forming in Ohio, Indiana, Illinois, Michigan, and Wisconsin, and said; "We are stating it very mildly when we say that ohio could send ten regiments in ten days to support the Union men of Kentucky, against invaders from Tennessee. Indiana has now $13,000 \mathrm{men}$ in camp. She could send them all to Louisville in three days. The military preparations of Illinois are enormous. Troops of that state are counted by brigades and at least ten regiments could be advanced from llinois into Kentucky in as many days. The states of Michigan, Minnesota, and Wisconsin have sent troops to the Potomac but each of these states has several regiments forming and just about ready. In case of a great emergency, such as the invasion of Kentucky by Secessionists, these regiments could be hurried to meet the invaders. We do not hesitate to assert it as our opinion that in ten days after a call for help from the Union men of Kentucky, 30,000 Northwest men would cross the Ohio River to their relief and in a fortnight 50,000 would go forward. The announcement that Secessionists had invaded Kentucky would electrify the Northwest and there would be such a rush to arms as was unheard of." 
The Louisville Journal re-published the article of which the above is but a brief extract on September 12, 1861 and did so, probably, because it was known that many people divided in their loyalties between the Union and the South might conclude that after all it would be the part of wisdom to be on the side of the largest battallions and to have the regiments of the Northwest come as friends rather than enemies.

Quotations from the papers of the period might be multiplied indefinitely. In giving these few I do not want to seem to subordinate the finer instincts of loyalty and devotion to the Union on the part of Kentucky people. I merely wish to show that neither press, nor platform, nor pulpit relegated arguments of material advantage to the background and that we to-day cannot afford to overlook them in trying to appraise the causes for Kentucky's adherence to the Union. Whatever were the elements that went into that momentous decision we know that it was the greatest blow for death to the South and that it was heralded and publicly celebrated throughout the North as its greatest victory. 
NOTES

(1) "Neutrality in Kentucky", by A. C. Quissenberry. Kentucky State Historical Society Register. 1917.

(2) The resolution passed by the House was never voted on by the senate nor was there any act or joint resolution passed on the subject of neutrality. On the last day of the session the senate passed (too late for the endorsement of the House) a resolution that was similar in sentiment to the one passed by the House - and due to that fact the people and indeed many historians have considered neutrality as if adopted by the Legislature.

(3) Collins - Annals. August 1, 1859.

(4) Editorial - Louisville Courier. July 26, 1860.

(5) Collins - Annals, Volume I. August 6, 1860. Vote - Combes (Bell - Everett candidate) $68,165$.

McClarty (Breckenridge candidate) $44,942$.

official returns - Courier, August 7,1860 .

(6) Editorial - Louisville Journal. August 8, 1860. 
1860.

$$
\begin{array}{lr}
\text { Bell and Everett } & 66,016 \\
\text { Breckenridge and Lane } & 52,836 \\
\text { Douglas and Johnson } & 25,644 \\
\text { Lincoln and Hamlin } & 1,366 \\
\hline \text { Total-............... } & 145,862
\end{array}
$$

Majority against Breckenridge 40,180

official returns in Louisville Journal.

November 27, 1860, differ slightly - giving almost a thousand more votes to Breckenridese.

(8) Bditorial - Louisville Journal. November 8 , 1860.

(9) Bditorial - Louisville Journal. November 10,1860 .

(10) Editorial - Louisville Journal. November 27,1860 .

(11) Vice-presidents appointed - W. A. Hauser, John Barbee, H. W. Bruce, Hamilton Pope, Joseph H. Harris, W. B. Hoke, Thomas W. Gibson, F. H. Simrall, C. Q. Armstrong, A. O'Bannon, and John Roberts. (12) Nominations from floor to Resolutions Committee - James Guthrie, Hon. W. H. Bullock, Col. John H. Harney, Hon. Joshua F. Bullit, Col. Davidson, Capt. L. H. Rousseau, and Col. Robert MoKee. Louisville Journal. November 27, 1860. (14) Journal of House of Representatives.

December, 1860. 
full in Journal. November 19, 1860. Editorial on same, November 22,1860 .

(16) Editorial - Louisville Journal. November

19. 1860 .

(17) Mr. Wickliffe's letter - Louisville Demo-

crat. November 11, 1860. Republished in Journal. November $12,1860$.

(18) Central Committee announced that they were acting in response to requests made by presidential electors meeting in Frankfort. Announcement signed by Orlando Brown - Chairman -, R. A. Buckner, Hamilt on Pope, F. H. Wilson, John Rodman, H. F. Todd, C. D. Carr, John M. Harlan.

(19) Full accounts of meeting in Louisville papers; Courier, Democrat, and Journal - January 9, 1861 .

(20) John H. Harney, George D. Prentice, Charles Ripley, Philip Tompert, Nat Wolfe, William F. Pope, Louis E. Harvie,

(21) Speed, Capt. Thomas - Union Cause in Ken= tucky, pp. $35-39$.

(22) Kentucky General Assembly Acts, Resolutions, and Reports relating to Civil War. (23) Editorial - Louisville Courier. December $16,1860$. 
(24) Editorial - Louisville Journal. December

17, 1860 .

(25) Governor's Proclamation, printed in full. Louisville Journal. January 17, 1861.

(26) Speed - Union Cause in Kentucky, page 27.

(27) Editorial - Louisville Journal. May 6, 1861.

(28) Speed - Union Cause in Kentucky, page 87.

(29) Quissenberry - "Neutrality of Kentucky in

1861". Kentucky State Historical Society Register,

1917.

(30) Mr. Breckenridge's address, printed in full. Louisville Journal. January 11, 1861.

(31) Ex-governor Helm's address, printed in full. Louisville Journal. December 5, 1860.

(32) Editorial - Louisville Journal. August 10, 1861.

(33) Editorial - Louisville Journal. January 16, 1861.

(34) Editorial - Louisville Journal. April 28, 1861.

(35) Editorial - Louisville Journal. April 27, 1861 .

(36) Louisville Journal. August 29, 1861.

(37) Simon Bolivar Buckner, a graduate of West Point and an officer of the Mexican War, was made Inspector-General with the rank of Major General, and was Commander of the State Guard, which was the ac- 
tive militia of the state, consisting of volunteers made into companies. As the machinery of the state was in the hands of men who had the same politics as the Governor it was natural that the State Guard was, in general, of the same political complexion. This fact was responsible for Union men organizing into volunteer companies afterward known as Home Guards and for the arming of the Home Guards by the introduction of what was known as the "Iincoln Guns". General Buckner, after the break up of Neutrality, joined the Confederate Army.

(38) Colonel Sam Gill - Superintendent of railroad from Louisville to Lexington. (39) Printed for the first time in MeElroy's Kentucky in the Nation's History, page 530. Similar account by Sam Gill, printed in Clarksville Jeffersonian, September 13, 1861 .

(40) The original of this paper was lost by General Buckner but fortunately it had been printed in the Clarksville Jeffersonian of Septemoer 13, 1861. A photograph of the text in McEIroy's Kentucky in the Nation's History, page 536.

(41) Henry C. Burnett - States' Rights candidate, 8988 votes. Lawrence S. Trimole - Union candidate, 6225 votes. States Rights majority - 2763. (42) Louisville Journal. August 30, 1861. 